\title{
ІМУННІ ТА МЕТАБОЛІЧНІ ПОРУШЕННЯ ПРИ РЕГУЛЯРНИХ ТА ІНТЕНСИВНИХ ФІЗИЧНИХ НАВАНТАЖЕННЯХ У СПОРТСМЕНІВ ВИЩОЇ ПРОФЕСІЙНОЇ МАЙСТЕРНОСТІ
}

\section{ДВНЗ «Тернопільський державний медичний університет імені І. Я. Горбачевського МОз України»}

РЕзЮМЕ. Моніторинг гуморальної ланки імунітету та непрямих маркерів фіброзу печінки спортсменів необхідно проводити в динаміці відповідно до графіку тренувально-змагальної діяльності, а також в умовах реабілітації. Він має бути комплексним, разом з оцінкою клінічних змін враховувати індивідуальні показники спортсмена.

Дані, отримані нами в результаті дослідження, будуть використані для подальшого вивчення патогенезу імунних та метаболічних порушень, які виникають при систематичних інтенсивних фізичних навантаженнях у спортсменів вищої професійної майстерності.

Організація імунологічного та біохімічного контролю функціонального стану печінки спортсменів вищої професійної майстерності, що тренують витривалість, а також розробка реабілітаційних програм і впровадження їх 3 метою корекції порушень імунологічної реактивності, яка виникає як наслідок відхилень від оптимуму фізичної активності, повинна підвищувати рівень здоров'я футболістів і позитивно вплинути на їх професійну результативність.

КлючовІ СловА: дисімуноглобулінемія; імуноглобуліни A, M, G; а-2 макроглобулін; гаптоглобін; реабілітаційна програма.

Вступ. Значні за обсягом та інтенсивністю тренувальні навантаження, які ставлять винятково високі вимоги до організму спортсмена, $\epsilon$ характерною рисою сучасного спорту [1]. Вирішення питання щодо участі імунної системи у розвитку адаптаційних реакцій організму у відповідь на стресові подразники різної сили при різному функціональному стані організму людини є актуальною проблемою $[2,3,5,9]$.

Центральним органом організму людини, що бере активну участь у всіх видах обміну речовин (білковому, вуглеводному та ліпідному) та виконує дезінтоксикаційну, захисну (проти бактерій та чужорідних речовин), бар'єрну та інші функції, $\epsilon$ печінка, саме в ній знешкоджуються шкідливі продукти обміну речовин. Печінка - єдиний орган, який вивільняє глюкозу для забезпечення адаптаційної діяльності органів і систем організму енергією. Вона має великі резервні можливості і здатна зберігати функціональну активність, незважаючи на пошкодження більшої її частини. Гепатоцити є паренхіматозними клітинами печінки, які в організмі людини виконують величезну кількість функцій [4]. При екстремальних станах в організмі спортсмена розвивається гіперферментемія, що є головним клінічним маркером розвитку гепатоцелюлярної недостатності [6].

Сучасний спорт вищих досягнень, який характеризується високими фізичними і нервово-емоційними навантаженнями, може негативно впливати на стан печінки та імунної системи організму спортсмена. Неадекватна організація тренувального процесу, недостатня його індивідуалізація, навіть за наявності компенсованих станів здо- ров'я, можуть призвести до виникнення патологічних проявів [7-9]. Імунореактивність спортсменів знижується, коли рівень функціональної готовності організму недостатній, а спортсмен через щільний графік тренувань та змагань не встигає відновлювати свої резервні можливості і змушений виконувати м'язову роботу. Зменшення адаптаційних можливостей є однією з причин того, чому з обережністю треба вводити до складу занять у підготовчому періоді великі обсяги тренувальної роботи. Має місце питання щодо причинного зв'язку між порушенням імунної системи, стану печінки та підвищенням захворюваності спортсменів вищої професійної майстерності, особливо в змагальний період $[5,7,11]$.

Футбол є видом спорту, який вимагає великих витрат енергії та завжди супроводжується розвитком в організмі футболістів тканинної гіпоксії та ендогенної інтоксикації.

Метою дослідження було вивчення реактивності імунної системи та біохімічних показників функціонального стану печінки спортсменів високої кваліфікації, які тренують витривалість, при тривалих і прогресивно зростаючих фізичних навантаженнях, створення реабілітаційних програм для травмованих футболістів з визначенням критеріїв, які 6 могли використовуватися для об'єктивної оцінки їх функціонального стану.

Матеріал і методи дослідження. Нами було обстежено 29 (22 здорових і 7 травмованих) спортсменів високого рівня кваліфікації віком 18-30 років, які займалися професійним футболом і перебували в режимі, який вимагав тренування і витривалості. Контрольну групу склали 26 здорових 
Огляди літератури, оригінальні дослідження, погляд на проблему, короткі повідомлення

нетренованих осіб ідентичного віку, а для 7 травмованих гравців було запропоновано реабілітаційні програми відповідно до їх захворювань.

Дослідження стану імунної системи та печінки організму спортсменів проводили після закінчення змагального періоду. У всіх обстежуваних зранку на 2 день після фінальної гри у венозній крові натще визначали вміст імуноглобулінів класів A, M, G та рівень а-2-макроглобуліну і гаптоглобіну методом імунотурбодиметрії за допомогою аналізатора Cobas 6000 та тест-системи Roche Diagnostics (Швейцарія).

Математичну та статистичну обробку результатів досліджень проводили на комп'ютері з використанням програмних пакетів Statistica 6.0 (StatSoft Inc., США) та Excel 2003 (Microsoft Corp., CША).

Результати й обговорення. Імунна система функціонує як багатокомпонентний та мультиваріабельний механізм, що пов'язано як з інфекційними факторами, так і з різноманітністю відповідей організму спортсменів, яка полягає в багатоплановості реакції гуморальної ланки імунітету, її своєрідності в кожному конкретному випадку на інтенсивні фізичні навантаження [3]. Аналіз імуноглобулінів класів A, M та G у футболістів вищої професійної майстерності має свої особливості. Необхідно звернути увагу на те, що надмірні фізичні і психічні навантаження в ході спортивної діяльності провокують численні дисфункціональні порушення в біохімічних системах, розвиток асептичного запалення, порушення кисневих режимів тканин, активацію реакцій вільнорадикального окиснення, пошкодження ендотелію судин, порушення мікроциркуляції тощо [8]. Як наслідок, суттєво підвищується навантаження на функціональний стан печінки та імунної системи. Фізичне перевантаження супроводжується швидкою і значною зміною обмінних процесів у печінці та імунній системі. Завдяки великим компенсаторним можливостям цих систем недовготривалі фізичні перевантаження не призводять до стійких функціональних порушень. Довготривалі фізичні перевантаження викликають значні зрушення внутрішньоклітинного обміну білків, вуглеводів, ліпідів, а також структурні зміни стану печінки (дистрофію гепатоцитів і значне розширення простору Діссе) і діяльності імунної системи $[4,10,12]$. Вплив на організм несприятливих факторів, в тому числі різних перевантажень, викликає в тканинах і органах всього організму спортсмена значні функціональні зміни [13]. Імуноглобуліни присутні у крові в двох основних складових, частина молекул знаходиться у вільному стані, розчинена в плазмі крові, а друга частина сорбована на поверхні клітин крові. Між ними існує динамічна рівновага, для зсуву якої в той чи інший бік достатньо мінімальних змін у гуморальному вмісті і фізико-хімічній характеристиці плазми крові. Зміни можуть бути зумовлені не тільки різними фізичними або психічними навантаженнями, але й фізіологічними реакціями, що мають місце в організмі. Наявність такого балансу може по-різному впливати на рівень імуноглобулінів у плазмі: з одного боку, протягом деякого часу нівелювати зміни кількості імуноглобулінів, що зумовлені особливостями їх продукції, з другого - при визначених (прогресивно зростаючих) навантаженнях призводити до різних коливань кількості імуноглобулінів у плазмі за рахунок швидкої сорбції молекул із плазми чи вивільнення їх до плазми. Все це в значній мірі приховує зміни у складі імуноглобулінів, що зумовлені розвитком патологічного процесу [3]. Необхідно зазначити, що для оцінки гуморальної ланки імунітету важливе значення мають індивідуальні показники фізіологічної норми окремо взятого спортсмена та етап його спортивної діяльності [2]. Тому для спортсменів вищої професійної майстерності було розроблено індивідуальні планові схеми дослідження функціонального стану печінки та гуморальної ланки імунітету на різних етапах тренувально-змагальної діяльності, а також розроблено реабілітаційні програми для травмованих футболістів. Наведені в роботі показники відображають зміни, які проявляються у футболістів лише після закінчення змагального періоду і $є$ одним з численних показників для оцінки функціонального стану в ході запланованої річної підготовки.

Ми розробили індекси для покращення діагностичної сили різноманітних лабораторних тестів, які базуються на комбінації непрямих маркерів фіброзу печінки. Найпоширенішою $є$ діагностична панель тестів, що включає визначення рівня а-2-макроглобуліну, гаптоглобіну, аполіпопротеїну A-1, ү-глутаматтрансферази та рівня загального білірубіну. Сироваткові неінвазивні тести сьогодні дозволяють визначити не тільки ступінь вираженості фіброзу печінки, а й її функціональний стан (рис. 1).

у 12 (54,5 \%) досліджених спортсменів реєстрували підвищення IgG, у 4 (18,2 \%) випадках підвищення IgA і в 2 (9,1%) - зниження IgM. У травмованих спортсменів спостерігали наступні зміни відповідно - у 4 (57,10\%), у 1 (28,50\%) та у 2 (14,40 \%). Підвищення концентрації імуноглобулінів у плазмі (переважно за рахунок IgG та IgA) часто має місце за рахунок реакції імунної системи у відповідь на впровадження чужорідних агентів, активацію автоімунних хронічних процесів або на травму, що спостерігалось у даному випадку (табл. 1). 
Огляди літератури, оригінальні дослідження, погляд на проблему, короткі повідомлення

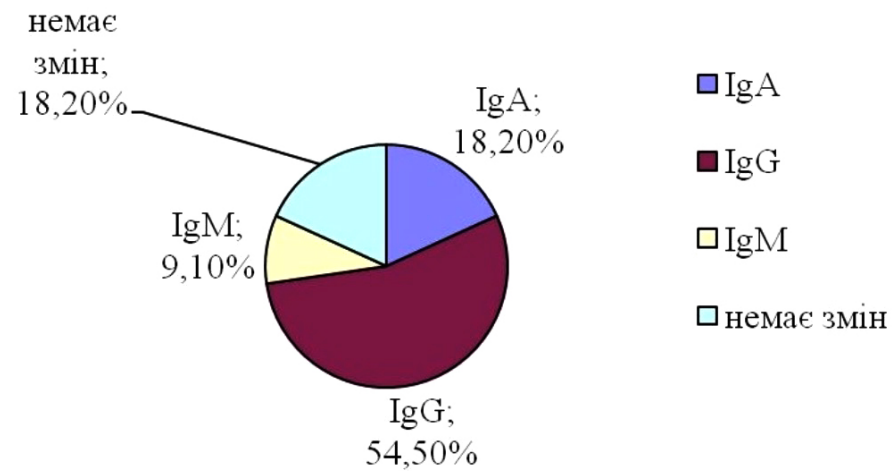

Рис. 1. Частота дисімуноглобулінемій у спортсменів вищої професійної майстерності.

Таблиця 1. Частота дисімуноглобулінемій у спортсменів

\begin{tabular}{|l|c|c|c|c|}
\hline \multicolumn{1}{|c|}{ Імуноглобуліни } & \% (здорові) & Кількість випадків & \% (травмовані) & Кількість випадків \\
\hline $\operatorname{IgA}$ & 18,20 & 4 & 57,10 & 4 \\
\hline $\lg \mathrm{I}$ & 54,50 & 12 & 28,50 & 1 \\
\hline $\operatorname{Ig} M$ & 9,10 & 2 & 14,40 & 2 \\
\hline Немає змін & 18,20 & 4 & - & - \\
\hline
\end{tabular}

В подальшому дослідження стану печінки та імунної системи проводили у здорових спортсменів, тоді як травмованим було запропоновано індивідуальні реабілітаційні програми, що включали руховий режим, комплекс відповідних лікувальних фізичних вправ, лікувальний масаж та раціональне харчування.

При дослідженні стану гуморальної ланки імунітету в спортсменів високого рівня кваліфікації виявлено значні зміни показників IgA, G і М у венозній крові, порівняно з контрольною групою (табл. 2). Імуноглобулін А виявився статистично достовірно вищим у досліджуваній групі, порівняно з контрольною $(4,98 \pm 0,39$ проти 2,74 00,21$)$. Показник імуноглобуліну G був статистично достовірно вищим у спортсменів високої кваліфікації у контрольній групі $(17,21 \pm 1,02$ проти 9,92 $\pm 0,72)$. Рівень імуноглобуліну М має тенденцію до зниження, порівняно з контролем $(0,77 \pm 0,66$ проти $1,71 \pm 0,45)$ (табл. 3).

Таблиця 2. Показники гуморального імунітету у спортсменів високої кваліфікації

\begin{tabular}{|l|c|c|c|}
\hline \multicolumn{1}{|c|}{ Імуноглобуліни } & $\begin{array}{c}\text { Спортсмени, } \\
\mathrm{n}=22\end{array}$ & $\begin{array}{c}\text { Контроль, } \\
\mathrm{n}=26\end{array}$ & $\mathrm{p}$ \\
\hline $\lg \mathrm{A}$ & $4,98 \pm 0,39$ & $2,74 \pm 0,21$ & $<0,05$ \\
\hline $\lg \mathrm{G}$ & $17,21 \pm 1,02$ & $9,92 \pm 0,72$ & $<0,05$ \\
\hline $\lg \mathrm{M}$ & $0,77 \pm 0,66$ & $1,71 \pm 0,45$ & $>0,05$ \\
\hline
\end{tabular}

Таблиця 3. Показники непрямих маркерів фіброзу печінки у спортсменів високої кваліфікації

\begin{tabular}{|l|c|c|c|}
\hline \multicolumn{1}{|c|}{ Імуноглобуліни } & $\begin{array}{c}\text { Спортсмени, } \\
\mathrm{n}=22\end{array}$ & $\begin{array}{c}\text { Контроль, } \\
\mathrm{n}=26\end{array}$ & $\mathrm{p}$ \\
\hline Гаптоглобін & $0,6 \pm 0,12$ & $1,32 \pm 0,11$ & $<0,05$ \\
\hline а-2-макроглобулін & $1,82 \pm 0,22$ & $2,31 \pm 0,17$ & $>0,05$ \\
\hline
\end{tabular}

Рівень гаптоглобіну виявився статистично достовірно нижчим у групі здорових спортсменів,

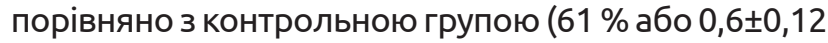
проти $1,32 \pm 0,11)$. Показники а-2-макроглобуліну у досліджуваній групі мають тенденцію до знижен- ня, порівняно з контролем (26 \% або 1,82 20,22 про-

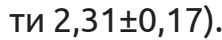

Висновки. Тривалий і прогресивно зростаючий вплив фізичних навантажень в організмі спортсменів високого рівня професійної майстер- 
Огляди літератури, оригінальні дослідження, погляд на проблему, короткі повідомлення

ності супроводжується імунопатологічними та метаболічними змінами. В більшості досліджуваних спортсменів вищої професійної майстерності реєстрували підвищення рівня імуноглобуліну G. В окремих спортсменів високої кваліфікації спостерігали підвищення рівня імуноглобуліну А та зниження імуноглобуліну М. Зміни показників гуморальної ланки імунітету свідчать про фізичні перевантаження більшої частини футболістів вищої професійної майстерності.

Інтенсивні фізичні навантаження в окремих спортсменів, які тренують витривалість, характеризуються зниженням рівня а-2-макроглобуліну i гаптоглобіну, тоді як у решти спортсменів досліджуваної групи такої тенденції не виявлено.

Організація імунологічного та біохімічного контролю функціонального стану печінки спортсменів вищої професійної майстерності, що трену- ють витривалість, а також розробка і впровадження адекватних реабілітаційних програм корекції порушень імунологічної реактивності, які виникають як наслідок відхилень від оптимуму фізичної активності, мають підвищити рівень здоров'я футболістів і позитивно вплинути на їх професійну результативність. Моніторинг гуморальної ланки імунітету та непрямих маркерів фіброзу печінки спортсменів має проводитися в динаміці відповідно до графіку тренувально-змагальної діяльності, у комплексі разом з оцінкою клінічних змін, має враховувати індивідуальні показники фізіологічної норми кожного окремого спортсмена тощо. Дані, отримані нами в результаті дослідження можуть бути використані для подальшого вивчення патогенезу імунних та метаболічних порушень, які виникають при регулярних та інтенсивних фізичних навантаженнях у спортсменів вищої професійної майстерності.

\section{ЛІТЕРАТУРА}

1. Ляпин В. П. Реакции системы крови у борцов / В. П. Ляпин. - Луганск, 2003. - 160 с.

2. Галій С. М. Вплив фізичних навантажень тренувального процесу на стан імунних та метаболічних показників у спортсменів, які займаються паверліфтингом / С. М. Галій. - Луганськ, 2007. - 16 с.

3. Лебедев К. А. Иммунограмма в клинической практике / К. А. Лебедев, И. Д. Понякина. - Москва, 1985. -224 c.

4. Гулак В. П. Гепатоцит, функционально-метаболические свойства / В. П. Гулак, А. М. Дудченко, В. В. Зайцев. - Москва, 1985.

5. Футорный С. М. Перспективы использования иммунологических методов в современной спортивной медицине / С. М. Футорный // Спортивна медицина. - 2004. - С. 49-54.

6. Козак Д. В. Фізична реабілітація та основи здорового способу життя : [навч. посіб. для студентів ВН3] / Д. В. Козак, Н. О. Давибіда. - Тернопіль : ТДМУ Укрмедкнига, 2015. - 199 с.

7. Baj Z. Immunological status of competitive cyclists before and after the training season / Z. Baj, I. Kantorski,
E. Maewska // Sports Medicine. - 1994. - P. 319-324.

8. Mitchell S. B. influence of carbohyclrate status of immune responses before and after endurawec exercise / S. B. Mitchell, F. X. Pizza, B. I. Paquet // J. Appl. Physiol. 1998. - Vol. 84. - P. 1917-1925.

9. Pedersen B. K. Exercise and the immune system: regulation, integration and adaptation / B. K. Pedersen, L. Hoffman-Goets // Physiol. Rev. - 2000. - No. 3. - P. 1055-1081.

10. Walter R. Essentials of Physical Medicine and Rehabilitation: Musculoskeletal Disorders, Pain and Rehabilitation [Edited by] / Walter R. Frontera, Julie K. Silver, Thomas D. Rizzo, Jr. - Philadelphia, PA : Saunders - Elsevier, Gardners Books - 2008.

11. Блюгер А. Ф. Успехи гепатологии / А. Ф. Блюгер, А. Я. Майоре. - Рига, 1982. - С. 12-34.

12. Футорний С. М. Профілактика і корекція імунологічних станів при заняттях спортом / С. М. Футорний // Спортивна медицина. - 2007. - № 1. - С. 49-54.

13. Гольбер Л. М. Очерки физиологии и патофизиологии гепатолиенальной системы / Л. М. Гольбер. Москва, 1977. - С. 10-15.

\section{REFERENCES}

1. Lyapin, V.P. (2003). Reaktsyi sistemy krovi u bortsov [Reactions of the blood system in fighters]. Lugansk [in Russian].

2. Halii S.M. (2007). Vplyv fizychnykh navantazhen trenuvalnoho protsesu na stan immunykh ta metabolichnykh pokaznykiv u sportsmeniv, yaki zaimaiutsia paverliftynhom [Influence of physical activity of the training process on the state of immune and metabolic indices in athletes engaged in powerlifting]. Luhansk [in Ukrainian].

3. Lebedev, K.A., \& Ponyakina, I.D. (1985). Immunogramma $v$ klinicheskoy praktike [Immunogram in clinical practice]. Moscow [in Russian].

4. Gulak, V.P., Dudchenko, A.M., \& Zaytsev, V.V. (1985). Gepatotsit, funktsionalno-metabolicheskie svoystva [Hepatocyte, functional-metabolic properties]. Moscow [in Russian].

5. Futornyy, S.M. (2003). Perspektivy ispolzovaniya immunologicheskikh metodov v sovremennoy sportivnoy meditsyne [Prospects of using immunological methods in modern sports medicine]. Sportyvna medytsyna - Sport Medicine, 49-54.

6. Kozak, D.V., \& Davybida, N.O. (2015). Fizychna reabilitatsiia ta osnovy zdorovoho sposobu zhyttia: [navch. posib. dlia studentiv VNZ] [Physical rehab and the basics of 
Огляди літератури, оригінальні дослідження, погляд на проблему, короткі повідомлення a healthy lifestyle: [manual for undergraduate students]. Ternopil: TDMU Ukrmedknyha [in Ukrainian].

7. Baj, Z., Kantorski, I., \& Maewska, E. (1994). Immunological status of competitive cyclists before and after the training season. Sports Medicine, 319-324.

8. Mitchell, S.B., Pizza, F.X., \& Paquet, B.I. (1998). Influence of carbohyclrate status of immune responses before and after endurawec exercise. J. Appl. Physiol., 84, 1917-1925.

9. Pedersen, B.K., \& Hoffman-Goets, L. (2000). Exercise and the immune system: regulation, integration and adaptation. Physiol. Rev., 3, 1055-1081.

10. Walter R. Frontera, Julie K. Silver, \& Thomas D. Rizzo, Jr. (Eds.). (2008). Essentials of physical medicine and

rehabilitation: musculoskeletal disorders, pain and rehabilitation. Philadelphia, PA: Saunders - Elsevier, Gardners Books.

11. Blyuger, A.F., \& Mayore, A.Ya. (1982). Uspekhi gepatologii [Advances in hepatology]. Riga.

12. Futornyy, S.M. (2007). Profilaktyka I korektsiia imunolohichnykh staniv pry zaniattiakh sportom [Prevention and correction of immunological conditions during sports]. Sportyvna medytsyna - Sport Medicine, 1, 49-54.

13. Golber, L.M. (1977). Ocherki fiziologii i patofiziologii gepatolienalnoy sistemy [Essays on the physiology and pathophysiology of the hepatolienal system]. Moscow [in Russian].

\title{
ИММУННЫЕ И МЕТАБОЛИЧЕСКИЕ НАРУШЕНИЯ ПРИ РЕГУЛЯРНЫХ И ИНТЕНСИВНЫХ ФИЗИЧЕСКИХ НАГРУЗКАХ У СПОРТСМЕНОВ ВЫСШЕГО ПРОФЕССИОНАЛЬНОГО MACTEPCTBA
}

๑В. В. Грушко

\author{
ГВУз «Тернопольский государственный медицинский университет имени И. Я. Горбачевского \\ МОЗ Украины»
}

РЕЗЮМЕ. Мониторинг гуморального звена иммунитета и косвенных маркеров фиброза печени спортсменов необходимо проводить в динамике, в соответствии с графиком тренировочно-соревновательной деятельности, а также в условиях реабилитации. Он должен быть комплексным, наряду с оценкой клинических изменений учитывать индивидуальные показатели спортсмена.

Данные, полученные нами в результате исследования, будут использованы для дальнейшего изучения патогенеза иммунных и метаболических нарушений, которые возникают при систематических интенсивных физических нагрузках у спортсменов высшего профессионального мастерства.

Организация иммунологического и биохимического контроля функционального состояния печени спортсменов высшего профессионального мастерства, тренирующих выносливость, а также разработка реабилитационных программ и внедрение их с целью коррекции нарушений иммунологической реактивности, которая возникает как следствие отклонений от оптимума физической активности, должна повышать уровень здоровья футболистов и положительно повлиять на их профессиональную результативность.

КЛЮЧЕВЫЕ СЛОВА: дисиммуноглобулинемия; иммуноглобулины A, M, G; а-2 макроглобулин; гаптоглобин; реабилитационная программа.

\section{IMMUNE AND METABOLIC DISORDERS IN REGULAR AND INTENSIVE PHYSICAL EXERTION IN SPORTSMEN OF HIGHER PROFESSIONAL SKILL}

๑V. V. Grushko

\section{Horbachevsky Ternopil State Medical University}

SUMMARY. Monitoring of the humoral link of immunity and indirect markers of liver fibrosis of athletes should be conducted in dynamics, in accordance with the schedule of training and competition activities, as well as in conditions of rehabilitation. It should be comprehensive, along with the assessment of clinical changes to take into account the athlete's individual characteristics.

The data obtained by us as a result of the study will be used for further study of the pathogenesis of immune and metabolic disorders that occur during systematic intensive physical exertion in athletes of higher professional skill.

The organization of immunological and biochemical control of the functional state of the liver of athletes of higher professional skill training endurance, as well as the development of rehabilitation programs and their introduction with a view to correcting the violations of immunological reactivity, which arises as a result of deviations from the optimum of physical activity, should improve the health of players and positively influence the their professional effectiveness.

KEY WORDS: disimunoglobulinemia; immunoglobulins A, M, G; a-2 macroglobulin; haptoglobin; rehabilitation program.

Отримано 10.11.2017 